\title{
Yoruba Traditional Education System: A Veritable Tool for Salvaging the Crisis Laden Education Systen in Nigeria
}

\author{
Ayanleke. R. Akinwale \\ School of Languages \\ Federal College of Education. P. M. B. 39, Kontagora. \\ Niger State, Nigeria
}

\section{Doi:10.5901/ajis.2013.v2n6p141}

\begin{abstract}
Long before the advent of the Europeans, the Yorubas $n$ the south western part of Nigeria developed a traditional educational system through which an individual behavior is moulded and directed towards their eventual role in the society. Ways, methods and techniques used by Yorubas may not be all that formal if compared with the modern day western education did not touch. Since education sector is like a factory that produces raw materials (human resources) for all other sectors of the society the focus of this paper is to foreground what could be learnt from Yoruba traditional education system to salvage the crisis laden education industry in Nigeria.
\end{abstract}

\section{Introduction}

In all societies, developed or developing, capital or socialist, traditional or modern. The common purpose of education is the transmition of accumulated wisdom, knowledge and skills from one generation to another and the preparation of the youths for the future membership and participation in the life of the society, in its maintenance, growth and development. The above conception is predicated on the fact that education ( being it indigenous or not ) has been very instrumental for the emancipation of individuals and the entire society from the shackles of ignorance, want, squalor and diseases. It is a path way to social and economic progress. The concept of education is a sequential process of developing the hidden and glaring potentials of a child. Education in this goes sense beyond the teaching for the purpose of exanimation which has been the main version of Nigeria education system ( Ayanleke, R. A 2012)

\section{Uniqueness of Yoruba Traditional Education}

Indigenous African education has been in existence before the introduction of western civilization into Africa. With the penetration of the Christian missions from the sixteen century, western culture has started to reach the various parts of Africa including formal education which main thrust was academic in the sense that every child is being prepared for higher education. Today, the idea of literacy and purely academic work which have dominated school curriculum all over Africa is being questioned in order to regain our hitherto rich, functional and life long indigenous education ( Adeyinka and Adeyemi 2002). Education is defined as defined as the process of cultural transmission and the process whereby the adult members of the society carefully guide the development of infants and young children, initiating them into the culture of the society ( Adeyemi and Adeyinka 2002).

The word education is derived from Latin words "educare" and "educare". Educare means to bring up, to rear, to guide, to direct, to educate. This implies that education is the process of 
bringing up children by adult members of the family and the society, a process of rearing, guiding, directing and educating children. From the explanation above, it means that the process of educating children are broad and are more than what the school alone can offer because education takes place within and outside the school.

Ocitti (1971). Identified five philosophical foundation or principles of African indigenous education which makes it affective, purposeful and life - long.

1. Preparation:- The role of learning and teaching was to equip boys and girls with the skills appropriate to their gender in preparation for their different roles in the society.

2. Functionalism:- This principle emphasizes the utilization nature of pre-colonial education, in which children learn through imitation, initiation ceremonies, work, play and oral literature. The learners become productive as they learn and are smoothly integrated into the community where they become functional and useful.

3. Communalism:- In African indigenous education, all members of the society owned things in common and applied the communal spirit to life and work.

4. Perennialism:-Education is the pre - colonial period as perceived on a vehicle for maintaining or preserving traditional and cultural heritage.

5. Holisticism:- African education provided little or no room for specialization, because boys and girls are equipped to undertake a multitude of occupations that required related skills. This holistic nature of indigenous education enabled young children to acquire a variety of skills that make them productive in many ways.

Yoruba indigenous education teaches children to imbibe these ethical values

- Knowledge of language

- Belief in God / spirituality

- Respect for God's creations

- Respect for nature

- Respect for elders

- Respect for others

- Love for children

- Hard work

- Spirit of sharing

- Spirit of co- operation

- Knowledge of family linage

- Avoidance of crime

- Avoidance of conflict

- Knowledge of family roles

- Love of humor

- Success through hard work

- Skills in hunting and farming

- Skills in dismotic work

- Responsibility to the largest community

- Defense of father land

One of the aspects of Yoruba traditional education is greetings. It is one of the most important virtues of the Yorubas which they always pass on to their children is respect for elders and reverence for one another. This is clearly demonstrated in greetings. As child grows up, he will be taught how to greet people. A boy prostrates while a girl knees down when greeting to show sign of respect. As the child grows up, he / she becomes used to this tradition. There is no event that Yorubas don't have greetings for, be it good or bad. Its through the act of greetings that the Europeans recognized the freed Yoruba slaves in Sierra Leone and called them "Aku language speakers". 
Yoruba traditional education also emphasize good, well behaved and disciplined society. It imposes on parents to ensure that their children are trained to respect elders and not to be disobedient to them.

Odu Iwori Meji ( I wori corpus) supports this by saying.

Bomode ba teriba fun baba re

Ohun gbogbo to dawole

A maa gun gege

I wa re a maa tutu pese pese

If a child respects his father

Everything he embarks upon

Will always be well

He will be a perfect gentleman

Another Ifa corpus (odu obara nyi) also condemns disrespect, pride and arrogance in youth.

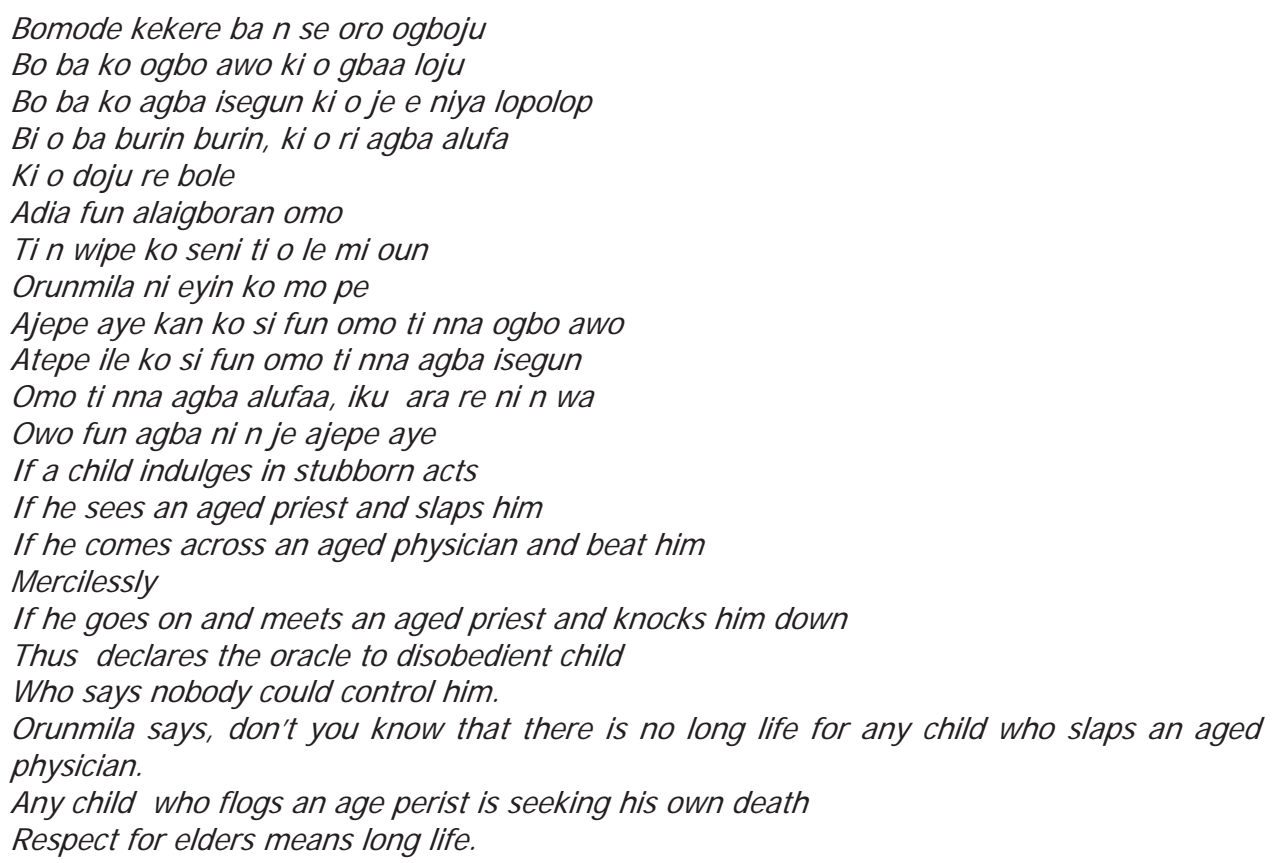

Yoruba traditional education revolves around good character (iwa), Yoruba lay more emphasis on I wa and it is the end product of all training that one gets from both home and society. If one in called Omoluabi ( a well behaved person) such person is regarded as a highly responsible person. It means such as person is from a good home, have a good character and has all it takes to be associated with. There is a clear difference between a popular person (gbajumo) and responsible person (omoluabi) somebody may be highly placed, wealthy, rich and popular but not responsible.

According to Yoruba history, Omoluabi means a child that in endowed with all the best gifts of mankind, like commitment, patience, love, respect and truth. "Olu I wa" is the Oduduwa, who is the father of all Yorubas. Yoruba believes that good characters is the most essential of all the attributes of a man, a man with a good character will also be endowed with all other good attributes.

Ogbe ogunda (ogunda corpus). Says. 
Inu mi o daa

Eni o maa gbele baba re

I wa mi o seeyan

Oode baba re ni yoo jokoo si

Ara mi kowosi

Oluwa re o delyin odi ni

A difa fori, a bu fun wa

I have a bad mind

Ask him to stay in his fathers house

My character is not human should not leave his father room

I ca't bear insults

Such a person has never got to another town

Ifa divination was peformed for ori

\section{Recommendations}

* Campaigns on re- appreciation of African culture should be canvassed. Africans should not view their culture as barbaric and inferiors to Europeans culture.

* The good and useful aspects of African indigenous history, philosophy, culture, customs and the traditions should be synthesized with valuabe aspects of western culture and incorporated in African school curriculum.

* Traditional religion studies should be introduced into our school system where morals and taboos will be taught to curb social vices in our society.

* Yoruba language which is the bases of learning Yoruba traditional education should be given a priority in our schools. Parents, teachers and government should encourage the use of Yoruba languages in our schools.

\section{Conclusion}

According to Lawal (2007), the contact of Nigerian culture with that of foreign culture has made it difficult for traditional education to have its primary objectives achieved. Many children can not greet elders not to talk of dressing properly. Nigerian culture is now giving way to foreign culture.

He further argued that the mother tongue which used to be a pride of every traditional society is no longer a thing of joy in many traditional homes as many Nigerian parents, prefer teaching their children how to speak English to their mother tongues.

Also, the games, the toys, the songs, the nursery, rhymes have no direct relationship with what the growing children are likely to encounter in their immediate environment and the effect of these alien resources is that instead of laying a social foundation for life long learning, Nigeria's early childhood education seems to be laying the foundation for the long inferiority complex and alienation.

According to Ifa corpus, in Odu irentegbe. It says

ohun ti a bi won bi kii wu won

Teni eleni ni ya won lara

A dia fun iwo dere

Ti selabarin eja

They are never inspired by their own historical legacy

The ones for the others are what they catered for

Cast divination for the fish hook

The close friend of fresh. 


\section{References}

Ayanleke R. A (2012) Re engineering cultural education through the tenants and teachings of African traditional institutions: Ifa institution as a case study: a conference paper presented at the 14th annual national conference of National Association for the advancenment of knowledge (NAFAK)Auchi Polytechnic Auchi 12th - 16th March. 2012.

Ayanleke R. A (2012) Ifa institution and moral education: a pragmatic approach towards rebranding education in Nigeria Article in Kontagora J ournal of education (KONJE) vol. 12 page 83 - 86, July 2012

Ayo, Salami (2008). Yoruba theology and tradition. The worship NIDD limited 8, Rashidi street Ilasamaja Lagos.

Adeyemi, M.B \& Adeyinka, A A (2002) Some key issues in African traditional education. McGill Journal of Education 20 (2) 1 - 5,.

Lawal. B. O (2007) African traditional education: Nigeria experience. General studies programme (GSP). Ibadan University of I badan

Ocitte, J. P. (1971) African indigenous education: As practiced by the Acholi of Uganda. Nairobi . East African Literature Bureau. 
